\title{
O HOMEM E O TEMPO EM SANTO AGOSTINHO
}

\section{ARTIGO ORIGINAL}

GOULART, Joender Luiz ${ }^{1}$

GOULART, Joender Luiz. O homem e o tempo em Santo Agostinho. Revista Científica Multidisciplinar Núcleo do Conhecimento. Ano 06, Ed. 12, Vol. 11, pp. 0530. Dezembro de 2021. ISSN: 2448-0959, Link de acesso: https://www.nucleodoconhecimento.com.br/teologia/santo-agostinho, $\quad$ DOI: 10.32749/nucleodoconhecimento.com.br/teologia/santo-agostinho

\section{RESUMO}

O presente estudo busca tratar os conceitos de tempo, alma e ser humano. Nessa perspectiva, tem como objetivo compreender o ente humano e sua relação com o tempo, a partir do pensamento de Agostinho. Para tanto, teve como questionamento norteador: se Agostinho é neoplatônico, será que também ele concebe o homem como essencialmente apenas a alma ou tem ele outra ideia de homem? Para realização do estudo foi utilizada pesquisa bibliográfica com base em autores que fundamentam a temática, incluindo nesse contexto, obras de Santo Agostinho. $O$ trabalho possibilitou concluir que o tempo é o que dá sentido à existência humana. $O$ ser do homem é temporal e transitório, sua marca é a finitude. O homem se constitui no mundo, com seus três êxtases temporais. O presente, o passado e o futuro não são compartimentos separados, mas constituem-se em única unidade, onde o mais importante é o futuro, porque o homem nele se constitui.

Palavras-chave: Tempo, alma, ser humano, Agostinho.

\footnotetext{
${ }^{1}$ Mestrando em Teologia Profissional. Pós-graduado em Filosofia e existência; Coordenação Pedagógica; Docência em Ensino Superior; Psicopedagogia. Bacharel em Teologia; Licenciado em Filosofia, Pedagogia e História.
}

RC: 104080

Disponível em: https://www.nucleodoconhecimento.com.br/teologia/santo-agostinho 


\section{INTRODUÇÃO}

A concepção filosófica de Santo Agostinho, caracteriza dentro da história da Filosofia, o pensamento medieval. Sua visão filosófica expressa uma articulação entre a racionalidade e a fé cristã. Sua filosofia teve influência do pensamento platônico e do cristianismo, enquanto seu conceito de experiência foi baseado na teoria de Aristóteles.

Passa-se do mundo antigo ao mundo novo mediante uma inflexão um tanto brusca, assinalada pelo advento do cristianismo. Naturalmente, esta mutação não acontece com demasiada rapidez, nem na história nem na filosofia; porém a falta de rapidez não suprime seu caráter conflitante. A alteração sobrevinda ao mundo grecoromano, por um lado, e à filosofia helênica, por outro, excedem o mero acontecer histórico em sentido rigoroso. Para se ater à filosofia, basta dizer que o pensamento filosófico que dominará a Europa, na Idade Média, não emerge da evolução interna do pensamento grego, mas sim da interpretação do mundo como realidade criada, sustentada ontologicamente no ser de Deus.

Foi neste contexto histórico que o pensador, na ânsia da busca apaixonada pelo saber, redige grandes tratados filosóficos e teológicos com o intuito de tornar consciente o saber para aqueles que tinham entrado em certa crise existencial e religiosa, devido ao declínio do império romano. Crise que se deu quando os bárbaros invadiram Roma e os cristãos quiseram retornar ao paganismo, porque acreditavam que os "deuses" pagãos os protegiam mais do que o Deus cristão. Então, Agostinho elabora dois assuntos inseparáveis que serão abordados aqui: a problemática da essência do ser humano e a do tempo.

Os neoplatônicos reduzem o homem essencialmente à alma. Neste contexto, o presente artigo visa responder: se Agostinho é neoplatônico, será que também ele concebe o homem como essencialmente apenas a alma ou tem ele outra ideia de homem? Baseado nesses questionamentos, o presente trabalho tem como objetivo esclarecer os conceitos de Agostinho sobre o tempo, a alma e o ser humano. Para isso, foi realizada uma pesquisa bibliográfica das principais obras de Santo 
Agostinho, assim como trabalhos relevantes de outros autores sobre o tema. $\mathrm{O}$ artigo discorre em torno da origem e a concepção da alma; o homem como imagem de Deus e sua tríplice constituição; a concepção de espírito e de corpo; a natureza do tempo e suas divisões e o conceito de eternidade.

O texto mostra ao leitor, o processo pelo qual Agostinho chegou à concepção física e metafísica do ser humano. O homem como um ente que contém em si a realidade material e imaterial, o corpo como algo físico, e a alma e o espírito como algo metafísico. $O$ texto também expõe a conceitualização feita por Agostinho em relação ao tempo como um ente racional, e sua respectiva divisão (passado, presente e futuro). Ele se refere ao tempo como algo passado, que não existe, enquanto o presente é o atual, que precisa passar para o pretérito para ser tempo. Já o futuro é o que ainda não existe.

\section{A ESSÊNCIA DO HOMEM E DO TEMPO EM SANTO AGOSTINHO}

\subsection{A ORIGEM E A CONCEPÇÃO DA ALMA}

O pensamento agostiniano gravita em torno de Deus e da alma. Em busca da compreensão da essência de Deus e da essência humana, Agostinho articula em sua relação a fé e a razão. Assim, a partir dessa articulação entre racionalidade e fé cristã, Agostinho busca, incessantemente, a sabedoria. Todo o itinerário do filósofo em direção ao conhecimento do homem, é uma narração de si mesmo, que revela um paradigma antropológico. Buscando o saber, o autor descobre o "eu," a realidade imaterial do ser humano. Para Agostinho, num dado momento da existência humana, é necessário dar uma pausa e indagar o que é a alma, e quem é, de fato, o Deus que Agostinho tanto almeja conhecer. E, assim, a partir dessa indagação, e por influência da filosofia platônica, da aristotélica e do pensamento de Plotino, Agostinho considera a alma como essência do homem. Portanto, compreender a alma é compreender a essência do homem.

Em busca do enigma do homem, Agostinho elaborou seu pensamento centrado em duas tradições distintas na concepção do que vem a ser o homem: a teológica, 
centrada no homem criado à imagem de Deus e a filosófica, que é representada na fórmula platônica: a alma encarnada no corpo e na aristotélica: animal dotado de razão. A primeira tradição sublinha o seu lado divino e a sua condição de pessoa, concebendo-o desde o alto, com imagem de Deus. A segunda, o lado empírico da natureza humana.

Baseando-se em ambas as tradições, Agostinho desenvolve o conceito de criação. Para Agostinho, se existe a criação é porque existe um Ser Criador, Deus. Um criador que fez todas as coisas ex nihilo. O mundo é criado por Deus do nada, o Ser Supremo o criou num estado de indeterminação e de imperfeição e gradativamente as várias formas se determinam e se especificam até a formação de seres sempre mais completos e fiéis. Deus, assim, colocou na matéria originária germes latentes, destinados a desenvolver-se com o envolver dos séculos: "O céu e a terra foram criados e estão sujeitos a mudanças e vicissitudes" (AGOSTINHO 1997, p. 333). Alguns seres criados aparecem na sua forma, como a alma, os astros etc. Outros com forma incompleta, porém dotados de virtudes intrínsecas evolutivas. Como exemplo disso, Santo Agostinho fala do primeiro homem e dos animais que se originaram da matéria bruta por evolução de alguns entes.

Então, o saber filosófico agostiniano, mostrando a natureza da estrutura íntima do humano, explicada pelas primeiras causas e supremos princípios, constitui-se em um saber primordial, pois não tem por objetivo dizer o que o homem tem ou que o homem faz, mas sim, o que o homem é. Por isso, Agostinho recorre às definições platônica, aristotélica e neoplatônica; principalmente ao sistema filosófico de Plotino para entender o conceito de Deus e do homem. Agostinho elabora, orientado pela filosofia grega e guiado pela revelação, que funciona em sua filosofia rigorosamente como um princípio heurístico[2], centrado na fé e na razão, o conceito de homem como a imagem de Deus.

\subsection{O HOMEM COMO IMAGEM DE DEUS}

Santo Agostinho, pela revelação bíblica, dá um novo alento à meditação ontológica do homem; descobre sua intimidade, alheia ao pensamento grego e, sobretudo o 
analisa do ponto de vista de seu ser, enquanto imagem de Deus. Esta posição é fecundíssima, porque obriga a propor a questão do ser pessoal do homem, que, na filosofia grega ficaria oculto ou quase ignorado. Ressaltar o homem como imago Dei é de suma importância para entender o pensamento de Agostinho.

Neste sentido, Santo Agostinho oferece o exemplo mais conspícuo de tradução da doutrina bíblica sobre a imago Dei na linguagem da filosofia platônica e neoplatônica. Em substância, a doutrina agostiniana é claramente bíblica. Tratando de imago Dei, o doutor de Hipona, parte sempre dos clássicos versículos do Gênesis: "Façamos o homem a nossa imagem e semelhança" (BÍBLIA, Gn, 1:27). E se houve, uma vez ou outra, oscilação no seu pensamento, isto se deve ao desejo de manter-se fiel às indicações do texto sagrado. Quanto à forma, todavia, Santo Agostinho a extrai sistematicamente do exemplarismo platônico.

O homem como imagem de Deus é o tema dominante da reflexão agostiniana. Só que é uma reflexão soteriológico. No entanto, o objetivo principal deste trabalho é conceituar, à luz da reflexão filosófica, a essência do homem. Todavia, é mister, primeiramente, entender o que seja a imagem de Deus à luz da teologia para que seja possível compreender o aspecto filosófico da questão.

O ser humano, segundo Agostinho, é formado por um ser supremo, Deus. A escritura diz que o homem foi formado por Deus à sua imagem e semelhança. Ao referir-se ao homem, o filósofo Agostinho refere-se à alma, como ser racional e vivente. Sendo assim, pode-se apresentar a fundamentação ontológica do homem enquanto este é imagem de Deus e Agostinho recorre à metafísica platônica da participação e da exemplaridade.

Então, para explicar a sua tese de que o homem é a imagem de Deus, o Santo parte de duas premissas fundamentais: a primeira é que a imagem de Deus no homem não pode consistir na parte material do ser humano, ou seja, no corpo; uma vez que a substância de Deus não é material: "O homem foi criado a imagem de Deus, não segundo a forma corpórea [...]" (AGOSTINHO, 1994, p. 376). A segunda premissa, é que a imagem de Deus no homem não se pode dar na parte inferior da realidade 
imaterial do homem, isto é, na alma, sendo que ela é suscetível à falha. Sendo assim, a imagem de Deus, com efeito, consiste no espírito, pois é a parte mais nobre do homem, que é uma substância imaterial não suscetível ao erro: "Não resta dúvida que o homem foi criado à imagem de quem o criou, não segundo alguma parte da alma, mas segundo o espírito, onde pode residir o conhecimento de Deus" (AGOSTINHO, 1994, p. 377).

Eis as grandes linhas da doutrina agostiniana sobre a imagem de Deus para evidenciar como essa imagem fornece ao santo vastíssima perspectiva, capaz de abranger e aprofundar todos os pontos fundamentais da antropologia, ou seja, a alma, o corpo e o espírito.

\subsection{O HOMEM E SUA TRÍPLICE CONSTITUIÇÃO}

Em sua obra Vida feliz, Agostinho se esforça para encontrar a definição de homem. Nesta obra, encontra-se uma discussão bem característica de seu pensamento, ou seja, o método socrático usado por Agostinho. No decorrer do diálogo, o autor indaga: "será evidente a cada um de nós, que somos compostos de alma, espírito e corpo?" (AGOSTINHO, 1998, p. 124).

O propósito do pensador, através desta questão, é desenvolver o composto humano e conhecer o homem em sua integridade. A determinação da compreensão do homem em Agostinho comporta outros elementos que compõem a totalidade do seu sistema. Assim é necessário estudar, com atenção, três elementos da concepção agostiniana de homem: o corpo, a alma e o espírito.

É preciso acentuar que, exatamente nesse ponto, encontra-se o motivo central da antropologia agostiniana. Aqui é mostrado, especificamente, o processo pelo qual Agostinho chega à concepção física e metafísica do ser humano. O homem como um ser tripartido, o corpo como algo físico, a alma e o espírito como algo metafísico. Sobre isso, escreve Agostinho nas Confissões:

São as três partes de que consta o homem: espírito, alma e corpo, que por outro lado se dizem duas, porque com frequência se denomina a alma 
juntamente como o espírito; pois aquela parte do mesmo racional, de que os brutos carecem, chama-se espírito; o principal de nós é o espírito; em segundo lugar, a vida pela qual estamos unidos ao corpo se chama alma; finalmente, o corpo mesmo por ser visível é o último de nós (AGOSTINHO, 1998, p. 411).

Após mostrar as três partes que constam o homem, isto é, o corpo, a alma e o espírito (visão profundamente arraigada no Cristianismo), são relevantes recorrer à filosofia antiga, precisamente, à filosofia platônica, para melhor entendimento do conceito do homem. Sendo que, foi a partir do estudo da filosofia de Platão que Santo Agostinho elaborou sua ontologia acerca do conceito de homem.

Embora seja notada a grande influência platônica na antropologia agostiniana, devese ter clareza que Agostinho seguirá Platão somente na doutrina da alma, acrescentando-Ihe outro elemento, que faz parte da essência da alma, o espírito. Porém, não na do homem; pois para Platão, como foi visto, o homem é somente a alma. Platão prega o dualismo de corpo e alma, isto é, os dois são antagônicos, antitéticos. O novo que Agostinho apresenta em sua antropologia é que a alma não é o homem, como afirmara Platão, pois o homem também é corpo e espírito.

Portanto, não se pode negar que Agostinho aproveitou a compreensão platônica de homem e escreveu seu tratado. Porém, introduziu lhes modificações profundas que torna tríplice a constituição humana - espírito, alma e corpo. Levando em conta a tese agostiniana que o homem foi criado por Deus, à sua imagem e semelhança, e que Deus é Trino, logo se pode inferir que o homem é composto também de Três elementos.

Deste modo, este composto de espírito, alma e corpo, intimamente ligados, chamase homem. Aliás, este nome não pode ser dado quando se fala de alma, espírito e corpo separadamente. Destarte, é na união substancial dos elementos spiritus, anima e corpus, que o homem se completa. Embora seja Agostinho de uma época que afirmava a separação entre o corpo e a alma, ele não afirma que a essência do homem seja um espírito e uma alma que se utiliza do corpo: "Não pode existir homem algum sem corpo, alma e espírito". (AGOSTINHO, 1998, p. 17). 
Agostinho é cônscio da problemática acerca do homem como um ser tríplice. Então, paulatinamente, em seu tratado filosófico, tem o cuidado de conceituar e provar a existência dos elementos que compõe o homem.

\subsection{ORIGEM DA ALMA, ORIGEM DO SER HUMANO}

Ao indagar sobre a origem da alma, Agostinho pergunta sobre a origem do ser humano. Segundo ele, a alma é que busca ter uma noção completa do ser humano, embora seja o composto de corpo, alma e espírito que constitui a unidade da pessoa. Para o autor das Confissões, a alma possui natureza própria de Deus, pois foi este quem a criou. Ela foi criada para dar vida ao corpo e, portanto, feita essencialmente para se unir a ele e formar um todo substancial próprio a cada indivíduo.

A alma humana teve origem na Trindade. Mas como se deu essa origem? A questão da origem da alma é confusa em Santo Agostinho. Sabe-se que Agostinho era um conhecedor da filosofia neoplatônica, que defende a tese da superioridade da alma em relação ao corpo. Também é notório, no pensamento agostiniano, que a origem da alma de Adão e Eva foram criadas diretamente por Deus. Porém, como se explica as almas descendentes de Adão e Eva?

Para o pensador Agostinho, é inadmissível a possibilidade de que as almas provenham por emanação da substância divina ou ainda preexistam como ensina Platão. Também não é aceita a eternidade da alma, mas sim a imortalidade. Então, apresentar-se-ão duas hipóteses principais dadas por Agostinho sobre a origem da alma: "todas as almas provêm de uma só, transmitidas por geração" (AGOSTINHO, 1995, p. 218).

A primeira, oriunda do traducionismo espiritualista, afirma que a alma de cada homem provém da alma de seus pais, do mesmo modo que o corpo é gerado pelo corpo de seus pais. Entretanto, defender essa tese é cair em contradição. Sendo que a alma é substância simples, sem composição, sem divisão e sem possibilidade alguma de mudança, como passará ela de pais para filhos? 
A segunda hipótese é que "a cada nascimento humano, uma nova alma é criada por Deus" (AGOSTINHO, 1995, p. 218). Constituindo-se, portanto, numa tese criacionista. Agostinho era inclinado a essa argumentação. Em O Livre Arbítrio, não defendera a tese como oficial, devido à dificuldade de explicar a transmissão do pecado original. Embora não tenha oficializado, a opção pelo criacionismo que é a aceita definitivamente pela tradição agostiniana.

Após apresentar a origem da alma, Agostinho propõe outra problemática acerca da substancialidade da alma. A filosofia agostiniana afirma que o ser humano é constituído de duas substâncias: a física e a imaterial. A substância metafísica tem, na sua constituição, dois elementos diferentes: a alma e o espírito. Não são termos sinônimos, absolutamente, mas são vocábulos que podem ser utilizados indiretamente para descreverem abreviadamente a substância imaterial do ser humano ou aspectos específicos e particulares dessa substância.

O problema da substancialidade da alma é uma questão que suscitou uma grande inquietação em Agostinho. Como foi afirmado anteriormente, o seu maior anseio era desvendar o mistério da alma e de Deus. Como foi apresentado, a alma foi criada por Deus, logo, tem substância própria: "é substância dotada de razão, apta a reger um corpo" (AGOSTINHO, 1997, p. 67). A Substância, porque está contida em si mesma, tem sua realidade própria. É dotada de razão.

A alma é, ainda, a parte superior do ser humano, e está incumbida de governar o corpo. A alma é como substância completa e se une ao corpo para animá-lo e vivificá-lo. Todavia, Agostinho não soube explicar qual é essa substância:

Se me perguntarem que é a composição do ser humano, respondo que ele é constituído de alma e corpo. O corpo é feito de quatro elementos (terra, ar, água e fogo). Quanto a alma, que atendo como substância própria, não saberia dizer de sua substância). (AGOSTINHO, 1997, p. 22).

Mesmo que não tenha explicado a essência da alma, Agostinho mostra a capacidade que a alma humana tem de conhecer coisas imutáveis e eternas. Para a alma conhecer as coisas imutáveis, é preciso que ela também seja imutável, é preciso que ela possua o caráter da imutabilidade e da eternidade. A alma é isenta 
de toda determinação corpórea: ela é imaterial; é espiritual. Embora seja isenta, ela está em toda parte do corpo, fazendo valer a totalidade de sua energia, tensão, intenção vital e cuidado. A alma, embora sendo uma substância, tem como objetivo animar e vivificar o corpo, que também é criado por Deus. Ora, a alma, não sendo igual a Deus, mas superior ao corpo, faz com que este se aproxime de Deus, porque são os dois imagem e à sua imagem e semelhança.

Agostinho concebe a alma como única e viva, tanto interna quanto externamente. A alma está em toda parte do corpo, fazendo valer a totalidade de sua energia, tensão, intenção vital e cuidado. Boehner e Gilson afirmam que, segundo Santo Agostinho, "o fundamento da união entre alma e corpo está na função mediadora da alma entre as ideias divinas e o corpo" (BOEHNER; GILSON, 1995).

Agostinho, para explicar a diferenciação conceitual de anima e animus, se utiliza do axioma: todo homem é um animal racional. O homem é um animal, é um ser que tem vida. Anima é o termo empregado para identificar o nível de realidade que tem vida, sendo atribuída essa característica aos seres animados ou animais. Sendo o homem um animal, ele indubitavelmente tem uma alma (anima).

Porém, o homem é um animal racional, possuindo, assim, atributos de racionalidade. Pelo fato de fazer uso da razão, se acresce uma diferença específica (animais que servem para identificar um certo grau de vida a que pertence; o exercício da razão). Então, animus designa especificamente a alma humana, em contraposição à alma animal (anima).

Partindo do pressuposto de que a alma (animus), é dada por Deus, ao homem a cada nascimento humano (tese criacionista) e que a alma tem como função dar vida ao corpo, Santo Agostinho chega à conclusão de que a alma humana é uma substância imaterial imutável, dotada de vida e razão que orienta o corpo humano. 


\subsection{TEORIA DA ILUMINAÇÃO COMO PROVA DA EXISTÊNCIA DA}

\section{ALMA}

Ao tratar da antropologia agostiniana, não se pode deixar de falar na teoria do conhecimento, que é a base da prova da existência da alma. $O$ homem é o único ser que tem uma alma (animus) racional, com a capacidade de conhecer; sendo o único que tem a faculdade cognitiva. Esta faculdade leva à capacidade de discernir o bem e o mal; constitui o intelecto, superior a todos os animais; propiciando a capacidade de reflexão de si e do mundo.

O homem também é o único ser com capacidade de julgar, porque tem consciência de si e julga o que está dentro de si, que é a verdade. Para Santo Agostinho, o homem precisa ter antes a ideia de verdade para, então, reconhecê-la. A vivência é a fonte do reconhecer e do conhecer. O objeto do conhecimento, para Agostinho, é a verdade. A verdade está na alma, na razão. A alma para conhecer, possui como norma uma verdade absoluta, a partir da qual a razão conhece e julga. A razão faz julgamento quando há compreensão das coisas exteriores, comparadas ao interior.

Mas, se o conhecimento não é formulado pelos sentidos, qual a sua origem, ou quem o gera? De onde vem esta possibilidade de "conhecer" e o ato de conhecer? A gnosiologia agostiniana alcança o seu remate com esta questão. Santo Agostinho fala de uma iluminação divina, a qual seria, juntamente com a inteligência, causa de geração das ideias. Portanto, não é dos sentidos, mas de Deus que procede o nosso conhecimento, bem como todas as coisas.

Dito isto, pode-se determinar especificamente na teoria da iluminação como prova da existência da alma. Santo Agostinho apresenta a verdade como segura e imutável. Ele acredita que no interior da alma humana existe uma valiosa certeza, ou seja, a verdade, advinda de Deus: "a alma e o corpo devem receber a verdade de outro ser, a perfeição imutável e eterna" (AGOSTINHO, 1995, p. 132). Agostinho em seu cogito afirma que a alma colhe a certeza de ser e de ser pensante. A alma conhece algumas verdades, sobretudo como princípio da não contradição e da 
própria existência, porque neste caso a dúvida é uma prova da existência. Se o homem dúvida que ele existe, então é porque ele existe, senão não haveria dúvida.

Quem duvida, no próprio ato de duvidar, tem consciência de si mesmo como dubitante; a certeza do próprio ser é indiscutível. Que o homem acredite ou duvide, afirme ou negue, ame ou odeie, é certa a consciência que o homem tem de si como ser existente. Então, ao afirmar que o homem é um ente pensante, Agostinho prova a existência da alma. O pensamento não é a alma; o ato de saber que pensa é o que afirma a existência da alma, porque a faculdade de pensar pertence à alma.

No seu aspecto objetivo, a consciência tem presente os princípios evidentes e universais (princípio de ordem metafísica, lógica, moral e representações intelectuais do mundo exterior, fundamento de todo conhecimento verdadeiro). A sua verdade é dada pela participação e semelhança (analogia) que elas têm com as ideias divinas e consequentemente com a verdade em si. Portanto, ao estudar o "inatismo" agostiniano, notar-se-á que a solução dada pelo próprio filósofo Agostinho, sobre a questão de como se dá o conhecimento, parte de um movimento central de inspiração platônica: o inatismo.

Para Agostinho, as ideias são inatas somente no sentido que o intelecto as exprime de si e não as tira dos dados sensíveis, a experiência sensível é apenas um estímulo, um ensejo, como para Platão, mesmo sendo verdadeira no seu grande conhecimento de particular. Enfim, para Agostinho, as ideias inatas são ideias presentes em nós. Mas não como dados depositados na alma do homem como afirmara Platão, porém como "presença" ativa e operante. Portanto, não há o inatismo platônico na filosofia agostiniana, mas presenciabilidade de princípios viventes.

Ao analisar a problemática gnoseológica agostiniana, pode-se interpretar seu pensamento como um idealista e imaterialista. $O$ idealismo agostiniano de origem platônica e de essência cristã afirma que todo o conhecimento é um produto do interior do homem, ou seja, espiritual. O conhecimento ou a verdade se dá quando, pela iluminação divina, a alma vê que a realidade estudada é conforme o protótipo 
das ideias que está em Deus desde toda a eternidade. Entretanto, o homem não tem uma visão direta de Deus quando acontece a iluminação. As razões eternas são objeto de nossa intelecção, é um processo natural, a verdade é dada ao intelecto e por ele intuído. Então, se pode concluir que a realidade do mundo dos objetos materiais está apenas na existência destes como ideias, primeiramente na mente de Deus e depois na mente do homem, que é criado por Deus.

\subsection{A CONCEPÇÃO DE ESPÍRITO}

O espírito humano é um elemento metafísico que faz parte da substancialidade imaterial do ser humano, como a alma. O autor das Confissões concebe a substância imaterial ordenada hierarquicamente. Embora seja uma única substância, existe em si duas partes: uma inferior e outra superior. Ou seja, a inferior é a alma, a superior, o espírito: "o espírito (spiritus) é a alma (animus), mas o que há de mais nobre na alma (animus) (AGOSTINHO, 1994, p. 494)". Entretanto, convém advertir que no sistema filosófico agostiniano o conceito de spiritus é complexo. Embora os termos spiritus e animus surjam como idênticos, Agostinho os coloca dentro de uma mesma substância, todavia, como seres separados.

Nesta questão do espírito como algo mais nobre do homem, nota-se que se trata de um problema de caráter teológico-filosófico, isto é, teológico devido ao dogma da criação; e filosófico, devido à teoria das ideias de Platão. Entretanto, é mister apresentá-la, com maior clareza, para entender a complexibilidade da concepção de homem em Santo Agostinho. Nesta temática do homem, já foi tratado anteriormente, em nível de esclarecimento, o homem como imagem de Deus, imago Dei. É necessário retornar à mesma questão para apresentar a totalidade da ontologia agostiniana.

Agostinho quer identificar a realidade imaterial que é o espírito, ao qual se reserva a capacidade de vir a ser a imagem de Deus, pois Deus é Espírito e o ser humano não poderá configurar-se à imagem divina senão mediante essa dimensão espiritual, ou seja, cada pessoa humana assemelha-se à Trindade em seu espírito. Ao analisar o termo em foco do ponto de vista da antropologia agostiniana, percebe-se uma 
referência feita ao espírito do homem como a natureza suprema de seu ser. Por ser a natureza suprema do homem, a metafísica agostiniana afirma que o espírito não está contido em uma forma, mas num contínuo devir. Porém, como é explicado esse devir do espírito para Agostinho?

Para Agostinho existe a igualdade reinante entre os três termos. Os três elementos consciência, amor e conhecimento, formam uma unidade perfeita. Não são três vidas, mas uma só; nem três espíritos, mas um só; da mesma forma, não são três substâncias, mas uma só: "Essas três coisas são uma única unidade" (AGOSTINHO, 1994, p. 290).

Em relação à unificação da pluralidade de funções do espírito, ela é unificada na substância anímica, pois é nessa substância que está o núcleo indestrutível do eu. Então, se pode, por esse motivo, mostrar a relação existente entre a alma e o espírito. "A alma se define como uma substância racional destinada a governar o corpo" (AGOSTINHO, 1997, p. 117), o eu, como última unidade. O eu que aninha todos os fios da vida anímica. $O$ eu que tem o atributo da consciência. $O$ eu que ama o seu interior. Portanto, quem é esse eu? Esse eu sou o espírito, a substância espiritual. Por isso, quando o espírito conhece a si mesmo, se conhece como substância, pois o eu sou um universo interiorizado no homem.

Assim, pode-se concluir que o espírito não possui só o conhecimento de outras coisas, como também de si mesmo, e assim, além de amar outras coisas, ele ama também a si mesmo. Consciência, amor e conhecimento, por conseguinte, são três disposições do espírito que são intimamente unidas entre si, de tal forma que não pode haver consciência sem conhecimento e sem amor, nem conhecimento sem consciência e sem amor, nem amor sem consciência e sem conhecimento. Com efeito, a tríade no interior do conhecimento humano possui, como a Santíssima Trindade: a consubstancialidade de três elementos: a consciência, o conhecimento e o amor. Logo, o homem é, intrinsecamente falando, a imagem de Deus, cujo espírito tem o reflexo divino, pois os atributos primordiais da Santíssima Trindade são: consciência, amor e conhecimento. 
Após o término da análise da realidade imaterial do homem, ou seja, da alma e do espírito em Santo Agostinho, passar-se-á ao estudo da problemática acerca da realidade física do homem, isto é, o corpo. Corpo que é o responsável pela consciência do mundo no homem.

\subsection{A CONCEPÇÃO DE CORPO}

Partindo da premissa de que o corpo é uma substância material, criada por Deus, deve-se apresentar a concepção de Agostinho sobre a realidade física do homem. Para o pensador, o corpo pertence à natureza do homem; assim, este não é somente alma e espírito, mas também corpo. O corpo faz parte da natureza humana. É a substância física do homem, a qual está presente a alma, e do qual ela é a vida: "existe certamente no corpo humano certo volume de carne, uma espécie, forma, ordem e distinção saudável. E este corpo é animado por uma alma racional" (AGOSTINHO, 1994, p. 117).

Para a nomenclatura agostiniana e filosófica, o corpo é sinônimo de matéria. É verdadeiro enquanto obra da criação. Faz parte do mundo sensível. Tem três dimensões: "não há corpo sem três dimensões. Não podemos supor a existência do corpo humano se este não apresentar longitude, latitude e profundidade" (AGOSTINHO, 1997, p. 32).

Outro ponto de grande importância em relação à problemática do corpo é a interpretação feita por Agostinho em relação ao conceito dado por Platão. Para Platão o corpo é apenas uma tumba ou cárcere, prisão da alma, o lugar para o cumprimento das penas. É raiz de todo mal, a fonte dos amores insensatos, paixões e erros. Essa ideia que Platão tem do corpo se dá devido a doutrina das ideias platônicas. Para Platão, o homem durante a vida não deve se ocupar com o corpo, uma vez que, os seus prazeres são efêmeros demais. Por isso, o necessário é libertar, o mais possível a alma de qualquer comunhão com o corpo. Pois este impede a aquisição da sabedoria. Pelos sentidos, ou seja, a visão e a audição, que são dois sentidos mais perfeitos, não levam ao conhecimento de forma rigorosa e segura. Somente no raciocínio puro é que se revela a verdade à alma. 
Mas, por que a alma e o espírito são imortais e o corpo é mortal? Agostinho explica que Deus, ao criar o homem em sua totalidade, o criou para a eternidade, para ser imortal; mas pelo livre arbítrio o próprio homem escolheu sua própria morte, isto é, pelo pecado original introduziu na substância física a mortalidade. A reflexão de Agostinho sobre o conceito de corpo quer demonstrar que o corpo existe como substância, embora mortal. Não quer demonstrar que o corpo é um instrumento a serviço da alma, se fosse assim, o corpo humano seria uma coisa a mais entre as coisas. Mas o homem só é homem, porque tem a sua substância física em conjunto com a espiritual. Substância que está no tempo e no espaço: "sinto o meu corpo no espaço e no tempo" (AGOSTINHO, 1994, p. 35).

Agostinho repete que o homem é formado de apenas duas substâncias: a natureza física e a natureza metafísica, sendo a primeira composta de um elemento apenas, que é o corpo, e sendo a segunda composta de dois elementos distintos que são a alma e o espírito. Quando Agostinho expõe a sua tese, afirmando que o homem é uma unidade substancial de corpo, alma e espírito; quis mostrar que a unidade substancial se dá na união entre alma e corpo. Embora contenham elementos substanciais diferentes no momento da junção, formam uma mesma unidade.

Após ter visto a exposição da ontologia agostiniana e a influência da ontologia platônica na agostiniana, pode-se aprofundar a questão do tempo em Agostinho, uma vez que a essência do homem faz parte da problemática do tempo. Portanto, será destacado que o tempo é a extensão da alma, um ente racional.

\subsection{TEMPO EM SANTO AGOSTINHO}

A partir de uma indagação realizada no livro XI das Confissões sobre a essência do tempo: "O que é realmente o tempo?" (AGOSTINHO, 1997, p. 342), Agostinho escreve sobre o tempo. Santo Agostinho fez o estudo sobre o tempo quando começou a questionar se a criação se deu na eternidade ou no tempo. Agostinho analisa as fases do tempo: o passado, o presente e o futuro, e conclui que antes da criação não havia tempo, havia somente Deus, eterno e estável. 
Para se entender a problemática acerca do tempo feita por Agostinho, é mister ter em mente que ele o concebe de duas maneiras: o tempo como momento da criação e o tempo como realidade. Tomando o primeiro, pode-se ver claramente que esta concepção de tempo abrange Deus como criador de todas as coisas e existente desde toda a eternidade. Já a segunda concepção abarca o homem a partir da criação e sua relação com o mundo circundante.

Sendo Deus o criador de todas as coisas, ou seja, de todo o universo e de tudo o que há nele, a afirmação de Agostinho é que não haveria um tempo antes da criação. No entanto, Deus não precede ao tempo, e sim, ele é anterior ao tempo, é eternidade ${ }^{[3]}$. Sendo Deus a origem de tudo, é ele, o também criador de todos os tempos, pois o tempo nasceu com a criação (AGOSTINHO, 1997).

O tempo é um agora que passa, nunca é totalmente presente. O passado é impelido pelo futuro. Todo passado e futuro são criados e determinados pelo ser presente: "Deus". A vontade de Deus não é criada, pois, está antes de toda criatura, nada seria criado se antes não existisse a vontade do criador, vontade que pertence a substância de Deus. Se antes do Verbo nada existia no céu e na terra, também não existia o tempo. Mas, Deus precede ao tempo, pois Deus é anterior a todos os tempos. A eternidade do criador esteve sempre presente. $O$ dia de Deus é perpétuo, o nosso, "criaturas", é cotidiano e finito. Para santo Agostinho, portanto, tempo é um vestígio de eternidade.

Em relação à segunda maneira como Agostinho concebe o tempo, ou seja, a concepção que abarca o homem a partir da criação, o pensador analisa o tempo como algo finito onde acontece a sucessão dos anos, dos dias, das horas; que envolve para o homem a noção de presente, passado e futuro. $O$ tempo se identifica com o temporário e o transitório, por isso, o tempo como tal é característico para a vida humana na terra. 


\subsection{A NATUREZA DO TEMPO}

Ao iniciar sua reflexão sobre a natureza do tempo, Agostinho refere-se a um paradoxo: ao fato de, ao mesmo tempo, saber e não saber o que é o tempo. Se alguém falar de tempo em seu colóquio corriqueiro, é sabido a que se refere; se for tentar definir o tempo, a complicação começa:

O que é realmente o tempo? Quem poderia explicá-lo de modo fácil e breve? Quem poderia captar o seu conceito, para exprimi-lo em palavras? No entanto, que assunto mais familiar e conhecido em nossas conversações? Sem dúvida, nós o compreendemos também o que nos dizem quando dele nos falam. Por conseguinte, o que é o tempo? (AGOSTINHO, 1997, p. 342).

Santo Agostinho caracteriza o tempo no aspecto psicológico. Perguntando pela maneira como acontece o aprendizado do tempo, ele não mostra preocupação pelo aspecto ontológico do tempo, mas afirma que o tempo é uma Distentio ${ }^{[4]}$ da alma: "Daí concluo que o tempo nada mais é do que extensão. Mas extensão de quê? Seria surpreendente, se não fosse a extensão da própria alma" (AGOSTINHO, 1997, p. 345). Agostinho não apresenta o caráter ontológico do tempo, mas, antes de tudo, a adaptação da alma à sucessão. Sua preocupação não é conceituar a essência do tempo. Sua preocupação maior é saber como medir o tempo e como conhecer a sua duração.

Após analisar as fases do tempo, ou seja, o passado, o presente e o futuro, Agostinho chegou à conclusão de que não havia o tempo antes da criação. Entretanto, após a criação surge o tempo nestas respectivas fases. Mas o que se entende de passado, de presente e de futuro na filosofia agostiniana?

\subsection{AS TRÊS DIVISÕES DO TEMPO}

O homem, ao perceber que existe a partir do passado, do presente e do futuro, se preocupa mais com o tempo que está passando e procura medi-lo. Mas o tempo que não existe não se pode medir. Pode-se medir o presente. O tempo é longo quando dura muitos anos, ou quando se espera muitos anos a vir? $\mathrm{E}$ o tempo é breve quando passa dez minutos ou quando se espera dez minutos a vir? Santo Agostinho 
interroga-se, dizendo: "Mas como se pode chamar de longo ou breve àquilo que não existe?" (AGOSTINHO, 1997, p. 343).

Agostinho questiona a existência dos três tempos. Se existe o tempo apenas que estamos vivendo (presente), o passado e futuro, que estão ocultos, não existem. Por que se fala deles? Não se pode ver o que não existe, o passado já existiu e o futuro está para existir.

Em relação ao passado é melhor dizer, afirma Agostinho, que foi longo; e do futuro será longo. E longo é apenas o momento que existia; uma vez passado, não mais existe e, portanto, não poderia ser longo, porque de fato, não existia. Mas não se pode dizer que o tempo passado foi longo, pois não se pode achar o que pode ter sido longo, desde o momento que uma vez passado, já não existe. Pode-se dizer que foi longo aquele tempo que é presente, porque é longo enquanto era presente e, ainda, não passou ao não existir e que, existindo, podia ser longo. Entretanto, uma vez já passado, não poderia ser longo, porque deixou de existir e não se pode medir o que não existe mais, o que um dia foi.

Ao falar das coisas passadas, que são palavras e não o fato em si, o homem as tem na memória. É possível memorizar, lembrar da sua duração enquanto foi presente. Santo Agostinho tinha esboçado o processo da lembrança do passado. Estão registradas na memória as imagens dos fatos acontecidos, que passaram pelos sentidos e marcaram o Espírito Santo.

Enfim, nem mesmo o ano, mês, ou dia, é totalmente presente, pois o ano é composto de meses que estão em constante movimento, em passagens e na total dependência de horas, segundos que, em seus movimentos, vão deixando de ser presentes e caem no passado.

Pode-se, no entanto, serem medidos os intervalos do tempo? Interpretando Agostinho, pode-se até mesmo comparar um tempo com outros e afirmar que uns são mais breves que outros, e que outros, são mais longos que outros. E se é possível fazer sua medida, é porque se percebe que eles vêm e passam. Todavia, 
aqueles tempos que passam, já não se pode medir, uma vez que, não mais existem. O que se pode afirmar que é medido é o que está passando.

E aqueles que narram coisas passadas, não poderiam relatar coisas verdadeiras, se não as vissem na mente. Ora, se o passado realmente não existisse, de modo algum poderia ser percebido. De onde se conclui que tanto o futuro como o passado existem (AGOSTINHO, 1997, p. 346).

O passado e o futuro existem. E onde quer que estejam não serão mais passados e futuro, porque eles, em si, não existem: o passado já passou e o futuro ainda pode vir. Em relação ao passado, ele existe enquanto memória, lembranças e imagens que são formuladas pelo homem como algo que aconteceu, e o futuro como algo que desejasse que acontecesse; e, aí, passado e futuro tornam-se presentes. Quanto ao passado, pode dizê-lo enquanto ideia, palavra e imagem, a partir de coisas já criadas, mas não é possível predizer o ato futuro, porque ele ainda não existe e as ideias e as imagens que são premeditadas não são mais futuros e sim presente, porque não é visto os acontecimentos e movimentos inexistentes das coisas em si, mas a imagem que formulamos na ideia. Por isso, é possível dizer que é futuro, porque ainda não veio, mas sim o presente, que é concebido pela mente. $\mathrm{O}$ futuro o homem o prediz, tornando-o presente. Mas o ato premeditado não pode ser presente; ele é futuro, está para acontecer. Santo Agostinho dá um exemplo claro:

Vejo a aurora e posso predizer que o sol está para surgir. O que vejo é a claridade, o fenômeno que é presente, e o que "prevejo" é o futuro. Não é futuro o sol, porque ele existe, mas é futuro o seu surgimento que ainda não nasceu (AGOSTINHO, 1997, p. 347).

Isso significa que é possível prever aquilo que existe e o que se conhece. Só se pode idealizar o futuro em cima de algo criado, existente e de conhecimento do homem. Ou seja, só é previsto o futuro porque o homem já o tem em sua imagem. Então, Santo Agostinho chega à conclusão de que os três tempos não existem. O presente dos fatos passados é a memória, o presente dos fatos presentes é a visão, o presente dos fatos futuros é a espera. No entanto, esses três tempos estão na mente. É possível medir o tempo enquanto ele passa. Quanto ao passado e futuro, não se pode medir porque não existem. O tempo é tomado no espaço e dá possibilidade ao homem de medi-lo. 
Há tempos mais longos e outros mais curtos, tempos simples, duplos e triplos. Santo Agostinho, aqui, se refere ao tempo de duração dos fatos. O tempo é o movimento dos corpos celestes. O tempo é uma espécie de "extensão". Por exemplo: "isto durou tanto quanto aquilo", ou "isto durou o dobro daquilo". Para Santo Agostinho o tempo não é movimento dos corpos, mas os corpos que se movem no tempo. O tempo é empregado pelo corpo para mover-se de um ponto a outro. O movimento dos corpos é medido pelo tempo.

Santo Agostinho afirma que o passado não é mais e que o futuro não é ainda. $O$ presente, se fosse sempre presente, e já não mais passasse para o passado; isto é, se transcorresse, não seria mais tempo, mas eternidade. O ser do presente, então, é um constante deixar de ser, pelos seus movimentos que o levam ao passado. Ainda afirma Santo Agostinho que, na verdade, o tempo só existe na alma do homem, é psicológico. Só no Espírito do homem, e através de sua memória, se mantêm os três tempos; passado, presente e futuro, que são vistos nas coisas e em nenhum outro lugar, a não ser na alma do homem. Embora tendo ligação com o movimento, o tempo não está no movimento e nem nas coisas que estão sempre em movimento, em oscilações, mas está na ideia, na memória e na intuição. Sua espera é totalmente psicológica, pois não é visto em parte alguma, não é material, não é cosmológico e não é astronômico. Enfim, do tempo se tem a memória, que guarda recordações, tornando-se objeto da atenção humana.

A memória passa a ser matéria de expectativa passada, presente e futura, que pode ser breve ou longa. O sentido de tempo, portanto, para Santo Agostinho, é totalmente "espiritual" e à luz da eternidade, que ele é interpretado.

Pode-se medir o tempo quando ele passa, além de só poder medir o que existe. $\mathrm{O}$ passado e o futuro não existem, e o presente não tem extensão; mas o homem o mede enquanto ele passa. Portanto, quando ele estiver passado já não se mede mais, pois não haverá nada mais a medir. Pode-se interpretar que para Agostinho a duração do tempo não será longa, se não se compuser de muitos movimentos. Ele só poderá vir do futuro e não pode passar pelo presente e não pode senão acabar senão no passado. Porque o tempo implica passado, presente e futuro. 
Mede-se o tempo, mas não existe, nem o que não tem extensão, nem o que não tem limites. E não se pode medir o futuro, nem o passado, nem o presente, nem o tempo que está passando. E, no entanto, se mede o tempo. Alguma coisa dele que fica "gravado," na alma, no momento em que vai passando e que permanece "gravado" mesmo depois que passou. Quanto ao passado, só existe na alma, sua memória. Não é o tempo que é longo, pois ele não existe, mas o longo futuro é a longa espera dele. E também não é longo o passado, mas a recordação dele. A lembrança que volta para uma atividade que já foi feita e para a espera de uma atividade a fazer. Só a atenção do homem, neste momento, ainda é presente, do qual o futuro torna-se passado. Então, pode-se afirmar que o tempo é um produto da alma, que o torna presente mediante a memória, no caso do ser passado; mediante a atenção no caso de ser atual; e mediante a espera, se é futuro.

Para Santo Agostinho o tempo tem origem em Deus e foi Ele quem o criou, dando-o movimento. E toda criação é um ato de verdade, um ato de Deus. Portanto é partindo da Eternidade que Agostinho interpreta a temporalidade. Diante desse pressuposto de que o tempo teve origem na eternidade, pode-se aprofundar o que consiste à eternidade para Agostinho.

\subsection{A ETERNIDADE EM SANTO AGOSTINHO}

"O que é a eternidade para o que teve começo? É a verdade para a fé"[5] (AGOSTINHO, 1994, p. 176). Agostinho, embora dizendo que a eternidade é uma questão de fé, tem como intuito refletir sobre ela nos parâmetros da razão. $O$ pensador recorre, ao mesmo tempo, à luz da fé e à razão para elaborar o conceito de eternidade. A razão é chamada para esclarecer os dados da fé: a eternidade como tempo que não passa. Se a teologia nos dá o conceito de eternidade, agora é preciso justificá-la pela razão.

Em relação à eternidade não se pode atribuir exatamente o que ela seja, isto é, não é possível definir a sua essência; entretanto, é possível falar dela e conceituá-la pela razão de forma análoga com o tempo humano. Por isso, Agostinho julga ser 
necessário demonstrar primeiro a existência de Deus, o qual para ele é o fundamento da eternidade.

Ao interpretar a teodicéia agostiniana, ou seja, a justificação da prova racional da existência de Deus, tem-se como objetivo específico provar a existência da eternidade, uma vez que, ao tratar da questão de Deus, estar-se-á tratando de um dos atributos do Ser de Deus: a eternidade. Então, poder-se-ia interrogar: Qual é o motivo que levou Santo Agostinho a desenvolver um tratado que justifique a existência de Deus, sendo que nunca duvidou da existência de algo?

O que levou Agostinho a justificar a existência de Deus foi o ceticismo de vários pensadores contemporâneos a ele. Agostinho, pela fé, sempre acreditou na existência divina. Porém como provar a existência do Transcendente aos incrédulos pensadores, uma vez que, não exercem a mesma fé que Agostinho? Então, já que é impossível aos céticos crer em Deus pelo exercício da fé sobrenatural, Santo Agostinho "abandona" os princípios da sua fé e elabora em seu sistema filosófico, a prova da existência de Deus e da eternidade baseando apenas na razão.

Em sua obra O Livre Arbítrio, Santo Agostinho discute com seu interlocutor, Évodio, a questão do livre arbítrio. Nesta discussão, Agostinho indaga a Évodio se ele está certo de que Deus existe: "Évodio, pelo menos uma coisa é certa para ti: Deus existe?" (AGOSTINHO, 1995, p. 77). A partir desta questão, Agostinho elabora suas teses que pretende comprovar a existência da divindade.

Como existem pessoas que não são "crentes", ou seja, que não acreditam em Deus pela via da fé, é mister um argumento incontestável para provar a existência de Deus. Assim, se apoiando em verdades racionais inteiramente seguras, o pensador de Hipona passa para a prova da existência de Deus, a partir da realidade dos seres criados.

Agostinho pergunta a Evódio se ele tem consciência de sua existência: "Assim, pois, para partirmos de uma verdade evidente para comprovar a existência de Deus e da eternidade, eu te pergunto: tu existes?" (AGOSTINHO, 1995, p. 80). Evódio 
concorda com Agostinho sobre a realidade da sua existência. Boehner e Gilson afirmam que é: "a primeira vez na história da filosofia que se depara com uma prova da existência de Deus e da eternidade na mais evidente das verdades, a saber: na existência da consciência conhecente" (BOEHNER; GILSON, 1970, p. 154).

Agostinho afirma que se Evódio existe, ele também vive e consequentemente tem o entendimento da sua existência. Essas três realidades, ou seja, o ser, a vida e a razão (entendimento), são três graus de perfeição nos seres humanos, sendo a razão a mais excelente das três, pois as outras duas, a inteligência e o viver, estão juntamente com a razão. Como forma de exemplo, pode-se dizer que toda pedra existe e que todo animal existe e vive. Todavia, a pedra não vive e o animal não tem entendimento de si, logo somente ao homem é possível ter a consciência que existe, vive e entende.

Por ser racional, ao homem também é possível julgar a si mesmo e o que está em sua volta. Então, dessa forma pode-se dizer que o homem é superior ao animal e vegetal, isso porque, quem julga sem ser julgado é superior e mais perfeito que aqueles que são julgados:

Com efeito, para todas as realidades inferiores à razão: os corpos, os sentidos exteriores e o próprio sentido interior, quem, pois, a não ser a mesma razão nos declara como é melhor do que o outro, e o quanto ela mesma ultrapassa-os a todos? (AGOSTINHO, 1995, p. 91).

Mas existe algo superior à razão? Eis Agostinho diante da seguinte problemática: é possível ultrapassar a razão humana? Baseando-se nesta questão, Agostinho formula a sua seguinte tese: "não há no mundo nada de superior à razão: pois o que dirias, Évodio é possível encontrar alguma realidade no mundo, cuja existência não só se conhece, mas também fosse superior à razão?" (AGOSTINHO, 1995, p. 92).

É notório que, no mundo, não há nada superior à razão, mas a razão intui verdades imutáveis e absolutas, que são superiores a ela, como por exemplo, a soma de dois mais dois são quatro. Essa é uma verdade universal e imutável. Por conseguinte, é mister que exista algo superior às verdades matemáticas, pois quem a julgaria correta a afirmação de que dois mais dois são quatro. A razão humana? A razão 
humana, com certeza, não é, porque a razão é mutável e por ser mutável é sujeita a erros. Então, existe uma sabedoria imutável, absoluta e transcendente que é criadora das verdades eternas e imutáveis. Seria Deus?

Agostinho chega ao apogeu da sua prova da existência de Deus, ou seja, há uma verdade eterna e imutável presente na razão humana, como foi citado, como exemplo, as verdades matemáticas; no entanto, tais verdades dependem de algo superior a elas. Então, esse algo superior se chama Deus, pois é eterno e imutável. Consequentemente, qualquer verdade, segundo Santo Agostinho, que tenha as características da eternidade, pode ser o ponto de partida para a prova da existência de Deus. Observa-se que a ideia de que a verdade é universal e eterna provém da metafísica grega, normalmente de Platão e neoplatonismo.

Desse modo, provar a existência da eternidade significa adquirir consciência da presença de verdades eternas e imutáveis no homem. Sendo assim, comprovada a existência da eternidade pela prova da existência de Deus, pode-se aprofundar a relação existente entre a eternidade e o tempo mutável.

\subsection{O CONCEITO DE ETERNIDADE}

Ao desenvolver a problemática acerca da eternidade, Agostinho mostra a distinção entre eternidade e tempo. A metafísica agostiniana assume duas dimensões no tempo: uma singular eterna e outra múltipla transitória. A primeira é a eternidade, categoria diametralmente oposta à temporalidade, porém, não é sinônimo de atemporalidade. Pois, se assim fosse, a ideia de eternidade seria uma espécie de refúgio, fora do mundo histórico e físico, um ópio do povo, algo inalcançável. $A$ segunda é o tempo com suas respectivas divisões: presente, passado e futuro. É o tempo de toda realidade. Então, poder-se-ia indagar: existe alguma relação entre as duas dimensões do tempo?

Agostinho, ao falar das duas dimensões do tempo mostra a relação existente entre ambas. O filósofo medieval afirma que antes da criação do céu e da terra não havia um tempo (presente-passado-futuro), um movimento sequer; havia um presente 
eterno, um único tempo de todos os tempos, a eternidade. Eternidade, que para Agostinho, é caracterizada não por uma ideia de independência de relação com o presente, com o passado e com o futuro, mas a eternidade que mantém a relação unificadora das duas dimensões do tempo: o transitório e o eterno. A eternidade que é a responsável para medir e reunir o todo passado, o todo presente e o todo futuro e transformá-los no eterno. Por isso, a eternidade é um perene presente, um sempre de novo; a cada vez que acontece a passagem de futuro para o presente, de presente para o passado, está a eternidade (Deus) exercendo a sua função, ou seja, medindo e transformando o tempo linear transitório em tempo singular. Todavia, poder-se-ia indagar: Por que a eternidade influencia o tempo plural intransitório?

Agostinho, então, esclarece essa indagação. Ao falar da eternidade, o pensador, está também falando de Deus que, para ele, é sinônimo de eternidade. Apresentar a eternidade como aquela que influencia o tempo plural é mostrar que a influência é possível, porque a eternidade-Deus é a criadora do tempo plural. Todavia, não é no tempo singular (imutável) que Deus precede aos tempos, porque se assim o fosse o Deus agostiniano não seria eterno, não seria anterior ao passado, presente e futuro. Dizia Agostinho, ao refletir sobre a eternidade:

Precedes, porém, todo o passado com a sublimidade de tua eternidade sempre presente, e dominas todo o futuro porque é ainda futuro, e, quando vier tornar-se-á passado. Tu, porém, és sempre o mesmo, e os teus anos jamais terão fim (AGOSTINHO, 1997, p. 342).

Os dias, anos ou meses, para o Deus de Agostinho não mudam, são estáveis e eternos, porque Deus é eterno. Mas por estáveis e eternos, Agostinho não entende que a eternidade seja uma permanência vazia, sem dinamicidade. Muitos interpretam a eternidade como a imagem de um Deus que se contempla eternamente com complacência e satisfação. Agostinho livrou-se dessa ideia questionável e a substituiu pelo conceito de eternidade, ou seja, a eternidade é a plenitude, completude do tempo total. Sendo a eternidade a completude do tempo, o tempo de Deus, o mesmo não se pode afirmar do tempo do homem; visto que os dias dos homens vão e vêm, estão em constante mudanças, a ponto de desaparecerem pois, não conseguem alcançar a totalidade do tempo. Quanto ao 
criador, ele é estável e imutável. Nada o coloca em movimento, em oscilação, ao contrário do homem, que vive num verdadeiro devir.

A filosofia agostiniana afirma que o tempo teve origem em Deus. O tempo é oriundo da eternidade, pois Deus é anterior a todos os tempos. Deus criara o tempo no instante em que proferiu a sua palavra: "Vós falaste e o tempo fora criado" (AGOSTINHO, 1997, p. 272). Entretanto, a fala de Deus não pode ser igualada a do homem, porque a fala do homem é passageira, foge e passa.

Foi pela fala eterna de Deus que o tempo foi criado. Pela fala, Deus deu vida ao céu e à terra e a todas as coisas que têm vida, colocando todas elas em movimento, espaços, percursos, rotações e duração. Assim, segundo a visão agostiniana, a temporalidade é expressão da palavra do próprio Deus:

Não houve, portanto, um tempo em que nada fizeste, porque o próprio tempo foi feito por ti. E não há um tempo eterno contigo, porque tu és estável, e se o tempo fosse estável não seria tempo (AGOSTINHO, 1997, p. 342).

As criações dos homens são eternas, devido a ideia de sua essência ser eterna na mente de Deus? Deus é criador, é eterno, não muda, não é passado e nem futuro. Ele é o eterno agora. Ele "cria" e "providencia" (providência), é origem e sustentação. Já o homem em seu aspecto físico aparece e desaparece no decorrer da história. E tudo que o homem cria, cria orientado por sua razão. Ele dá forma a algo já existente, porém essa matéria usada não é por ele criada. O homem cria baseado em algo já existente, diferente de Deus que cria do nada, então se pode concluir que a criação do homem não é eterna. Eterna é a ideia de homem na mente de Deus, diferente da criação do homem. Mas a matéria utilizada pelo homem ao criar algo, é eterna? Deus criou o mundo no tempo; assim a matéria é transitória temporal. Ela sofre suas mudanças e variações no espaço e tempo. Muitas coisas criadas pelo homem, inclusive, deixam de existir com o passar do tempo.

Assim, o ato da criação de Deus não acontece no tempo; a criação do homem é temporal, transitória, porque ele é constituído no horizonte da temporalidade. Antes da criação, tudo era só eternidade. Deus criara tudo, pois nada então existia. Só Ele, 
desde toda eternidade, existe. O tempo e as coisas mutáveis, foram criados, pensados e proferidos pelo eterno, sem nenhuma sucessão de pensamento. Isto porque, à Deus pertence a eternidade e, portanto, a posse simultânea e total de todos os momentos. O tempo só tem sentido para o homem.

\subsection{METODOLOGIA}

A metodologia refere-se em como será conduzido o projeto, abrangendo o estudo dos métodos e os meios disponíveis para chegar a um resultado, com a finalidade de captar e abordar o assunto de forma satisfatória.

[...] a metodologia é o conjunto de recursos técnicos de apreensão da realidade e nos serve para a obtenção dos dados empíricos e seu processamento, nos auxiliando na mensuração do objeto de estudo. Apesar de não conter a essência deste, é fundamental para melhor apreendê-lo. (LAKATOS; MARCONI, 2010).

É importante que o desenvolvimento de uma pesquisa seja consistente para que possa mostrar, de forma eficaz e segura, aquilo que se pretende atingir. A temática da pesquisa foi norteada por um processo de investigação situado na metodologia de pesquisa bibliográfica. No presente trabalho de pesquisa, busca-se descobrir novos conceitos sobre um determinado fenômeno. A saber: $\mathrm{O}$ homem e o tempo. $\mathrm{O}$ artigo foi elaborado a partir de leituras, resumos e aprofundamento bibliográfico em obras do próprio Santo Agostinho e de outros autores que tratam de temas agostinianos, conforme está na referência bibliográfica.

\section{CONSIDERAÇÕES FINAIS}

A realização deste trabalho demonstrou que Agostinho mergulhou profundamente em si mesmo, no seu eu, realizando reflexões importantes em busca da verdade. Mas, como Agostinho era um homem de fé, seus conceitos filosóficos nasciam e se mesclavam, muitas vezes, com noções teológicas.

De acordo com seus escritos, esta busca ávida e árdua pela verdade, foi uma constância ao longo de seu caminho existencial. Foi por meio de momentos 
angustiantes e inquietantes, no recôndito de sua alma, que ele elaborou a sua filosofia ontológica e o conceito de tempo mutável (presente, passado e futuro) e da totalidade do tempo: a eternidade.

Agostinho muito questionou sobre a relação entre o tempo e o homem. Entendeu o homem como um ser composto de realidade física e metafísica, ou seja; corpo, alma e espírito. Sendo que, o espírito é a parte mais nobre do homem, pois é a imagem de Deus. Ainda dentro do estudo da essência do homem, Agostinho provou a existência do homem pela teoria do conhecimento. Afirmou que o homem existe, porque tem a faculdade de duvidar. Antes da criação, isto é, antes de Deus criar o céu e a terra, não havia tempo algum, só havia a eternidade. Portanto, é partindo da eternidade que Agostinho interpreta a temporalidade.

O tempo nasceu com a criação, isto é, nasceu o movimento que pode ser longo ou breve, que fica a depender do seu movimento. O passado, presente e futuro existem como memória e ideia. O passado já passou e o futuro ainda pode vir. Eles existem enquanto memória e expectativa; nelas o passado e futuro tornam-se presentes.

A argumentação agostiniana sobre o homem e o tempo revela a grande responsabilidade que o ser humano tem nas mãos, isso porque, pertence a ele a opção de se amadurecer, visto que o tempo existe para burilar a pessoa humana. Contundo, é mister, segundo Santo Agostinho, a abertura do homem para o seu próprio ser e para o Ser Supremo, porque virá um período em que o tempo mutável dará seu último suspiro e não se falará mais dele, e então falar-se-á da prolixidade ininterrupta da eternidade. Portanto, é no tempo que o homem precisa desvelar todo o seu ser, para que a sua saída do tempo mutável para a eternidade não seja o seu fim, pois para uns, segundo Santo Agostinho, a eternidade será o começo sem fim, para outros será o fim sem fim e sem recomeço.

\section{REFERÊNCIAS}

AGOSTINHO, Santo. A Vida Feliz, Tradução: Nair de Assis Oliveira. 2.ed. São Paulo: Paulus, 1998.

Disponível em: 
https://www.academia.edu/5349908/SANTO_AGOSTINHO_A_vida_feliz. em: 25 out. 2021.

AGOSTINHO, Santo. A Trindade, Tradução: Agustino Belmonte. São Paulo: Paulus, 1994. Disponível em: https://portalconservador.com/livros/Santo-Agostinho-ATrindade.pdf. Acesso em: 25 out. 2021.

AGOSTINHO, Santo. O Livre Arbítrio, Tradução: Nair de Assis Oliveira. São Paulo: Paulus, 1995. Disponível em: http://www2.uefs.br/filosofia-bv/pdfs/agostinho_03.pdf. Acesso em: 25 out. 2021.

AGOSTINHO, Santo. Sobre a potencialidade da alma, Tradução de Aloysio Jansen de Faria. Petrópolis: Vozes, 1997. Disponível em: https://docero.com.br/doc/80cc85. Acesso em: 25 out. 2021.

BíBLIA. Gênesis. Português. In: Bíblia sagrada, Reed. Versão de Antonio Pereira de Figueiredo. São Paulo: Ed. Das Americas, Cap. 1, vers. 27.

BOEHNER, Philotheus.; GILSON, Etiene. Santo Agostinho, o mestre do Ocidente. In: História da Filosofia Cristã: Desde as origens até Nicolau de Cusa, Petrópolis: Vozes, 1970. Disponível: https://docero.com.br/doc/sxxv0vn. Acesso em: 25 out. 2021.

BOEHNER, Philotheus.; GILSON, Etiene. História da Filosofia Cristã, 4. ed. Petrópolis: Vozes, 1995. Disponível: https://docero.com.br/doc/sxxv0vn. Acesso em: 25 out. 2021.

LAKATOS, Eva Maria; MARCONI, Marina de Andrade. Fundamentos de Metodologia Científica, 7.ed. São Paulo: Atlas, 2010. Disponível em: http://docente.ifrn.edu.br/olivianeta/disciplinas/copy_of_historia-i/historia-ii/china-eindia/view. Acesso em: 25 out. 2021. 


\section{APÊNDICE - REFERÊNCIAS DE NOTA DE RODAPÉ}

1. Heurístico - conjunto de regras e métodos que conduzem à descoberta e a resolução de problemas.

2. Por eternidade Agostinho entende que é um presente que não passa, é um agora permanente. Na eternidade nada passa, tudo é presente.

3. Distensão é nada mais nada menos que o presente, levando em conta o passado e o futuro, como presente realizado e ainda por realizar, respectivamente. Este conceito de tempo (distensão) é baseado na filosofia de Plotino.

4. Quantum ad id quod ortum est aeternitas valet, tantum ad fidem veritas.

Enviado: Novembro, 2021.

Aprovado: Dezembro, 2021. 